\title{
The Impact of HR Strategy on Organizational Effectiveness
}

\author{
Sami Ahmed Alghamdi \\ Bisha Business School, Bisha University, Bisha, Saudi Arabia
}

Email address:

sami.alghamdi@yahoo.com

\section{To cite this article:}

Sami Ahmed Alghamdi. The Impact of HR Strategy on Organizational Effectiveness. American Journal of Theoretical and Applied Business. Vol. 6, No. 4, 2020, pp. 91-97. doi: 10.11648/j.ajtab.20200604.16

Received: September 30, 2020; Accepted: December 4, 2020; Published: December 11, 2020

\begin{abstract}
Organizational effectiveness is becoming ever more essential, particularly in the more dynamic marketplaces that involve greater competition. Organizational effectiveness promises the continuation of an organization's competitiveness in a global market. Human resources are crucial to maintain an organization's presence in the marketplace. These human resources must be managed carefully to achieve an organization's required performance. To succeed strategically, it is essential to focus on human resources and tailor them to the organization's strategy. In the past few decades, the field of human resource management has been characterized by continued growth. However, different organizations perceive human resources to have different roles. Some organizations argue that a human resource management strategy is essential in enhancing organizational efficiency. This is because the human resource strategy is seen as influencing decisions made regarding the overall operation of the organization. Conversely, other organizations believe they are already operating efficiently and consider the utilization of a human resource strategy to be a luxury. Such organizations perceive human resource management as inconsistent with the dynamic nature of their operations. This paper aims to describe the role of the human resource strategy in increasing the efficiency of organizations. It will present a set of concepts that have proven successful in doing so.
\end{abstract}

Keywords: HR Strategy, Organizations, Effectiveness

\section{Introduction}

One of the results of globalization was that organizations (companies and institutions) worldwide found their economic, financial, and legal environments characterized by immense and rapid changes, making the vast world a small village. As such, restrictions imposed by countries aiming to protect their local industries no longer existed. Additionally, the freedom of movement and circulation of goods and services has increased tremendously, which has sparked intense competition among global, local, and regional organizations and companies.

These results have imposed environmental conditions and changes that are different from the reality that prevailed in the past. They have imposed on organizations the necessity to adapt quickly to, rather than collide with, the changes. Consequently, organizations have adapted their general strategies, management strategies, and practices in all areas of operation-whether production, human resources (HR), sales and marketing, administration, or employment structures, among others-to internal and external environmental changes.

One of the operational areas requiring comprehensive change and adaptation is human resource management (HRM). It was not possible to retain the term "personnel management" (as it was called before 1980), as major universities replaced it with HRM. This change was not limited to the name but extended to the content and role. HRM has become a strategy of its own, fused into the overall organizational strategy, and is an integral part of many organizations. As a strategy, HRM plays a vital role in achieving the objectives of the organization's overall strategy.

\section{Literature Review}

\subsection{HR Strategy}

A business strategy can be defined as a set of strategic choices, some of which are formally planned. HR planning is the process of analyzing organizational needs as far as human capital is concerned and consistently adapting them to organizational goals and objectives. The business strategy in any organization must be considered when developing the 
HRM strategy. Joining the two elements plays a crucial role in exposing any deficit that may exist in the organization as far as human skills and proficiencies are concerned [26]. Moreover, it also helps in the identification of unexplored opportunities that could improve organizational operations.

Strategic human resource management (SHRM) is mainly oriented towards implementing strategic changes and developing the organization's skill base. According to [13], this ensures that an organization can remain competitive. SHRM enhances the growth of human capital that enables the organization to develop its competitive advantage. This way, the organization can achieve its goals and objectives much more quickly. HRM is a vital element when developing the strategic plan of any organization. It ensures that the strategy leads to the achievement of the organizational goals.

\subsection{Standards for Measuring Organizational Efficiency}

Organizational performance can be rated using different approaches. There exists a relationship between the effectiveness and efficiency of $\mathrm{HR}$ policies and organizational performance [12]. The achievement of organizational goals and increase in profits can be considered the most obvious factors in assessing the efficiency of the strategies in place. However, how is the efficiency of an organization measured from the perspective of HRM? Several studies have proven that organizations that employ effective HR practices, such as encouraging employee participation in decision-making, enabling employees to work freely, and improving the communication environment, have produced better results than organizations that follow conventional practices [6].

On the operational side, the efficiency of organizational performance can be assessed through employee turnover, employee productivity, moral motivation, and job satisfaction, as well as through the effectiveness of job succession programs and cultural/ethnic diversity in the work environment. More importantly, it can be also be measured by matching the company's values to all the operations that individuals in the organization perform [9].

Different organizations use diverse metrics to assess their organizational performance. Training and development, talent acquisition, HR planning, and performance reviews are some of the standards that organizations use to measure the efficacy of their HR policies.

\subsubsection{Training and Talent Development}

Business performance is directly linked to the quality of the recruited HR [19]. Many organizations implement training and development programs to increase employee skills and knowledge [16]. Training can comprise formal teaching sessions or knowledge transfer from an expert. High-performing organizations usually have well-trained employees, and the HR department must rate highly in this metric. Developing talent calls for deliberate steps to recognize and reward excellent performance, and includes attrition and promotion strategies [13]. Good organizational performance requires the retention of top performers and the strengthening of talent pipelines. Ultimately, high employee retention and performance rates are directly proportional to organizational performance.

\subsubsection{Talent Acquisition}

Effective recruitment and selection processes are essential to getting the right HRs and maintaining high organizational performance [14]. Reference [20] describes some critical developments in the hiring and selection process, especially concerning their focus and sophistication. The recruitment process is mainly based on business strategy. This allows an organization to acquire the appropriate quantity and quality of HRs, especially after job analysis. It also ensures that all the job posts and skills required are filled [30]. Reference [24] claims that the reward system is essential for employee attraction and retention. It is also necessary for organizations to maintain a stable working environment and remain competitive. This ensures that the employees provide the best quality of services, mainly because it enhances the ability of organizations to motivate their staff members and establish an efficient performance management strategy.

\subsubsection{Performance Reviews}

A study conducted on KPMG employees found that most respondents agreed that objective performance appraisals impact organizational performance [18]. According to this study, performance appraisals contribute to increased employee motivation and positively impacte organizational performance and job satisfaction. Performance reviews involve establishing attainable goals and objectives based on measurable targets, against which a rating is obtained in consideration of target attainment. These reports are essential in rewarding top employees. They are also vital in identifying employee weaknesses, information which the HR department and managers rely upon to determine how best to assist affected employees to improve their performance. Scholars recommend regular performance reviews and continuous exercises to help identify training needs [17].

\subsubsection{HR Planning}

HR planning is described as forecasting the demand and supply of HRs within an organization, and developing strategies that integrate the two [15]. With increasing competition, many organizations are faced with several HRrelated challenges that require HR departments to engage in planning activities. The people-related parameters include employee recruitment, safety, communication, motivation, remuneration, training, and wellness [11]. Delivering high organizational performance requires managers to monitor these parameters continually, to determine their impact on performance. The responsibility for maintaining a state of readiness in response to any changing variable lies with the HR department, due to its acknowledged impact on organizational performance. Effective HR strategies should be intertwined into the overall organizational strategy, to ensure that the former works to achieve the latter. HR planning, training and development, performance reviews, and talent acquisitions are standards against which all 
organizations should measure themselves to determine the efficacy of HR policies in advancing organizational objectives.

\section{Methods}

This study aims to establish the impact of HR strategy on organizational effectiveness. The study relies on data collected through reading and analyzing related publications. The secondary research referred to publications made in this area, different academic debates, and analysis of different past study findings. These publications have been published in various journals, conferences, and books. The selection strategy for these publications followed three steps. The first step involved screening the title and abstract of the publication to ensure they included the required information. The next step comprised an assessment of the full text of the remaining studies to ensure they follow the inclusion and exclusion criteria. In this stage, the search hits were reduced to 14 studies, which are included in this article. The third step involved checking the biography of the summarized studies; these are listed in Table 1.

The inclusion criteria were that articles had to: (1) focus on matters relating to SHRM; (2) have practical utility; (3) be published in a peer-reviewed scientific journal; and (4) follow both quantitative and qualitative methods. The exclusion criteria were studies that: (1) focused on nonstrategic HRM practices; or (2) had an unclear framework.

\section{Results}

Different associated studies were referred to during this research, and included a wide array of industries, such as manufacturing, service, power, engineering, banking, education, and transportation.

Table 1. Summarized Studies.

\begin{tabular}{|c|c|c|c|c|c|}
\hline Author/year & Industry & Sample & Study design (tool) & SHRM practices & Results \\
\hline Saunders, 2009 & Strategic HR & $\begin{array}{l}70 \\
\text { employees }\end{array}$ & $\begin{array}{l}\text { Qualitative } \\
\text { approach; } \\
\text { longitudinal study }\end{array}$ & $\begin{array}{l}\text { Using HR power and strong } \\
\text { culture to acquire or gain } \\
\text { competitive advantage. }\end{array}$ & $\begin{array}{l}\text { With a team of } 70 \text { individuals, } \\
\text { the change in legislation made } \\
\text { the corporation susceptible to } \\
\text { risks associated with lack of the } \\
\text { HR function over the past } 5 \\
\text { years. }\end{array}$ \\
\hline Anon, 2006 & $\begin{array}{l}\text { Service } \\
\text { organizations }\end{array}$ & 0 & $\begin{array}{l}\text { Qualitative } \\
\text { approach; } \\
\text { literature review }\end{array}$ & $\begin{array}{l}\text { Employee voice and } \\
\text { participation, internal career } \\
\text { ladders, result-oriented } \\
\text { performance appraisals, } \\
\text { employment security, formal } \\
\text { training systems, and } \\
\text { performance-based } \\
\text { compensation. }\end{array}$ & $\begin{array}{l}\text { Larger organizations with } \\
\text { technological savvy that depend } \\
\text { on independent contractors' work } \\
\text { tend to appear very likely } \\
\text { implementers of SHRM } \\
\text { practices. }\end{array}$ \\
\hline $\begin{array}{l}\text { Chang and Huang, } \\
2005\end{array}$ & Manpower & $\begin{array}{l}338 \\
\text { employees }\end{array}$ & $\begin{array}{l}\text { Quantitative } \\
\text { approach; } \\
\text { questionnaires }\end{array}$ & $\begin{array}{l}\text { The product market effect } \\
\text { strategy involving the } \\
\text { relationship between SHRM and } \\
\text { firm performance. }\end{array}$ & $\begin{array}{l}\text { The contingency model validity } \\
\text { of the Asian society was } \\
\text { confirmed. }\end{array}$ \\
\hline $\begin{array}{l}\text { Becker and } \\
\text { Huselid, } 2006\end{array}$ & Management & 0 & $\begin{array}{l}\text { Qualitative } \\
\text { approach; } \\
\text { literature review }\end{array}$ & $\begin{array}{l}\text { The strategy integrating } \\
\text { implementation as the central } \\
\text { mediator in the relationship } \\
\text { between variables. }\end{array}$ & $\begin{array}{l}\text { There was a clear articulation of } \\
\text { the "black box" for HR and firm } \\
\text { performance. This emphasized } \\
\text { the integration of implementation } \\
\text { strategy as the central variable } \\
\text { medium. }\end{array}$ \\
\hline Al-Awlaki, 2018 & Financial Scoter & $\begin{array}{l}335 \\
\text { managers }\end{array}$ & $\begin{array}{l}\text { Quantitative } \\
\text { approach; } \\
\text { questionnaires }\end{array}$ & $\begin{array}{l}\text { Skill management as the linking } \\
\text { factor in Yemeni commercial } \\
\text { banks. (The study analyzes the } \\
\text { direct and indirect association } \\
\text { between SHRM and the } \\
\text { development of organizational } \\
\text { innovation.) }\end{array}$ & $\begin{array}{l}\text { There is a relationship between } \\
\text { SHRM, organizational creativity } \\
\text { development, and knowledge } \\
\text { management. The commercial } \\
\text { banking management realized the } \\
\text { importance of SHRM to achieve } \\
\text { competitive advantage and that it } \\
\text { could be the source of creative } \\
\text { ideas. }\end{array}$ \\
\hline
\end{tabular}




\begin{tabular}{|c|c|c|c|c|c|}
\hline Author/year & Industry & Sample & Study design (tool) & SHRM practices & Results \\
\hline & & & & & $\begin{array}{l}\text { from } \mathrm{HR} \text { as far as training and } \\
\text { guidance is concerned. }\end{array}$ \\
\hline Anuradha, 2013 & $\begin{array}{l}\text { Social science } \\
\text { and } \\
\text { interdisciplinary } \\
\text { research }\end{array}$ & $\begin{array}{l}42 \\
\text { respondents }\end{array}$ & $\begin{array}{l}\text { Quantitative } \\
\text { approach; } \\
\text { survey } \\
\text { questionnaire }\end{array}$ & $\begin{array}{l}\text { Occupational management of } \\
\text { staff. }\end{array}$ & $\begin{array}{l}\text { Occupational management of } \\
\text { staff through motivations and } \\
\text { stress management was made } \\
\text { viable by appropriate strategy } \\
\text { and planning of resources. }\end{array}$ \\
\hline $\begin{array}{l}\text { Al Adresi and } \\
\text { Darun, } 2017\end{array}$ & $\begin{array}{l}\text { Engineering } \\
\text { business } \\
\text { management }\end{array}$ & $\begin{array}{l}331 \\
\text { employees }\end{array}$ & $\begin{array}{l}\text { Quantitative } \\
\text { approach; } \\
\text { structured } \\
\text { questionnaire }\end{array}$ & $\begin{array}{l}\text { Employee voice and } \\
\text { participation, internal career } \\
\text { ladders, result-oriented } \\
\text { performance appraisals, } \\
\text { employment security, formal } \\
\text { training systems, and } \\
\text { performance-based } \\
\text { compensation. }\end{array}$ & $\begin{array}{l}\text { Employees or workers get more } \\
\text { committed to the duties of the } \\
\text { organization they work for when } \\
\text { they are offered the best SHRM. }\end{array}$ \\
\hline $\begin{array}{l}\text { Catriona et al., } \\
2000\end{array}$ & $\begin{array}{l}\text { Service industry } \\
\text { management }\end{array}$ & 31 & $\begin{array}{l}\text { Qualitative } \\
\text { approach; } \\
\text { in-depth interviews }\end{array}$ & $\begin{array}{l}\text { The frequent replacement of staff } \\
\text { with an aim of providing } \\
\text { enthusiastic and motivated } \\
\text { service to customers at the lowest } \\
\text { cost to the organization. }\end{array}$ & $\begin{array}{l}\text { The study describes a multiple- } \\
\text { case analysis of four call centers } \\
\text { and explores the sacrificial HR } \\
\text { strategy used. The contingencies } \\
\text { in the strategies leading to the } \\
\text { appearance are determined. }\end{array}$ \\
\hline Armstrong, 2000 & $\begin{array}{l}\text { Personal } \\
\text { management }\end{array}$ & 0 & $\begin{array}{l}\text { Qualitative } \\
\text { approach }\end{array}$ & $\begin{array}{l}\text { Developing and implementing } \\
\text { HR for an integrative, coherent, } \\
\text { and mutually supportive role. } \\
\text { Ensuring support for the business } \\
\text { and value addition adoption } \\
\text { throughout the HR function. } \\
\text { Utilizing the ethical dimension of } \\
\text { HRM. }\end{array}$ & $\begin{array}{l}\text { SHRM process involves people } \\
\text { working both individually and } \\
\text { collectively to contribute to the } \\
\text { achievement of organizational } \\
\text { objectives. }\end{array}$ \\
\hline $\begin{array}{l}\text { Brewster and } \\
\text { Hegewisch, } 2017\end{array}$ & $\begin{array}{l}\text { Policy and } \\
\text { practices in HR }\end{array}$ & 0 & $\begin{array}{l}\text { Qualitative } \\
\text { approach }\end{array}$ & $\begin{array}{l}\text { Overall strategy, industrial } \\
\text { relations, duty and education of } \\
\text { HR professionals, employee } \\
\text { recruitment, capacity building, } \\
\text { training and development, } \\
\text { payment process, } \\
\text { communication, equal } \\
\text { opportunities, flexibility, and EU } \\
\text { social policy. }\end{array}$ & $\begin{array}{l}\text { Evidence of SHRM trends are } \\
\text { portrayed through several areas } \\
\text { including overall strategy, } \\
\text { industrial relations, duty and } \\
\text { education of HR professionals, } \\
\text { employee recruitment, capacity } \\
\text { building, training and } \\
\text { development, payment process, } \\
\text { communication, equal } \\
\text { opportunities, flexibility, and EC } \\
\text { social policy. }\end{array}$ \\
\hline $\begin{array}{l}\text { Batarlienè et al., } \\
2017\end{array}$ & $\begin{array}{l}\text { HR in transport } \\
\text { companies }\end{array}$ & 0 & $\begin{array}{l}\text { Qualitative } \\
\text { approach }\end{array}$ & $\begin{array}{l}\text { Analysis of employee } \\
\text { performance, needs planning for } \\
\text { the labor force, and recruitment } \\
\text { of new candidates, selection of } \\
\text { candidates, orientation and } \\
\text { training of the new employee, } \\
\text { administration of wages and } \\
\text { salaries, education of employee } \\
\text { commitments, and creation of a } \\
\text { fair and safe environment to } \\
\text { work. }\end{array}$ & $\begin{array}{l}\text { All employees participate in the } \\
\text { establishment and } \\
\text { implementation of every strategy } \\
\text { of the company. Employees are } \\
\text { tasked with "unity function," that } \\
\text { is, to work together as a team and } \\
\text { ensure that both individual well- } \\
\text { being and organizational success } \\
\text { are achieved. }\end{array}$ \\
\hline Sana et al., 2016 & Education & 0 & $\begin{array}{l}\text { Qualitative } \\
\text { approach }\end{array}$ & $\begin{array}{l}\text { The ladder-type academic } \\
\text { program for the health } \\
\text { professionals in education. }\end{array}$ & $\begin{array}{l}\text { The MOU and agreement } \\
\text { between two universities } \\
\text { pertaining to work performance } \\
\text { with WHO-WPRO was the most } \\
\text { useful tool to inform what is to } \\
\text { be done, by whom, and at what } \\
\text { stage of the program (The SHRM } \\
\text { structure). }\end{array}$ \\
\hline
\end{tabular}

\section{Discussion}

To increase the effectiveness of organizations, certain mechanisms for making sustainable HR strategies must be applied. Maintaining close contact between the HR department and employees through efficient communication is an essential aspect of the HR strategy. According to [21], this ensures that all the employees are well informed about changes in corporate policies and procedures. Most organizational managers acknowledge that the HR strategy is vital to enhancing their operations. Moreover, [22] describes 
how high-commitment HR management practices influence employees' effectiveness. This emphasizes that organizational leaders should consider implementing the HRM strategy to enhance positive perceptions on the employees' side, as this would further extend their favorable attitudes and mannerisms.

Reference [27] involves a study of the Abu Dhabi Distribution Company, which finds that most of the company's employees are happy with their supervisors because the supervisors assist and care for them. This is mainly because the HR department in the company has an open-door policy that allows employees to complain about any issues arising among them. The HR department responds to repetitive supervisory complaints by referring both the complainant and the supervisor involved to the committee that finalizes the issue.

There are other studies that establish the importance of HRM in organizational development. For example, [29] indicated that strategic HRM promotes learning and development in organizations. With strong HR support, line managers tend to accept their new roles and become able to effectively manage them. This leads to further organizational development.

In addition, there is a positive correlation between HR strategies and organizational innovation and skills management. Organizations that have a higher interest in HRM strategy tend to have a greater ability to develop organizational innovativeness and manage their skills effectively. A strategy that promotes organizational effectiveness also promotes the ability of the company to grow, survive, and compete [1].

Reference [2] found that SHRM is expected to be instrumental in motivating employees, as indicated by the study on Libyan oil and gas companies. Therefore, motivational strategies, such as compensating employees based on their achievements, should be employed. This is essential to ensure that HRM strategies are compatible with organizational operations and increase employee engagement It is also recommended that corporate leaders understand the internal needs of the organization to ensure that the implemented strategy leads to the achievement of organizational goals. Therefore, it is the role of corporate leaders to guide the implementation and execution of the SHRM practices. Attention must also be paid to different crucial elements of the organization. This includes developing the organizational objectives, linking the motivation and reward system directly to accomplish the desired outcome, and initializing policies and processes for the proper strategic implementation of strategies.

Reference [2] also indicated that SHRM plays a significant role in improving the healthcare sectors in the Philippines and the Kingdom of Cambodia, by instructing the healthcare providers in those countries [28]. In Cambodia, the training of different healthcare professions has promoted collaboration among them. This has further increased the opportunities to break "silos," which otherwise would have prevented effective transformative training. This is mainly because the graduates and students undertaking courses in the different healthcare professions are allowed to perform the roles in their respective institutions. Consequently, the healthcare sector in Cambodia has continued to grow and remains competitive globally.

Reference [10] points out that HR plays an important role in increasing productivity and, hence, in promoting improved customer service performance. Leaders should share decisions related to the strategy with their work teams from the beginning of the planning stage. Integrating decision-making with strategies facilitates effective management and implementation of organizational goals. Some companies engage their customers and make an impression of their strategies. For example, Southwest Airlines has mastered the art of applying this concept. The company sends selected customers to the company's headquarters in Dallas to participate in the process of selecting front-line employees. Providing such participation to their customers is a beneficial step, since they are the ones who will be directly dealing with these employees in the future. According to [3], customer participation is important in organizational decision-making processes.

Several studies have shown that there is a clear relationship between strategy and improvement in performance. Furthermore, scholars have observed that different ways of implementing organizational strategies directly affect the performance of such organizations. It is important to point out that a thorough understanding of the internal and external factors contributes to improved organizational performance [7]. This opinion is echoed by [5], which provides as an example an oil services company seeking to understand its limited market share. From the study, it emerges that the company's HR team suggested a questionnaire to evaluate customer satisfaction and the company's knowledge of their purchase criteria in terms of price, quality of service, accessibility, and distribution. Before disclosing the results of the questionnaire, the team asked members of management the primary criterion that they believed affected the purchase decision. Members mentioned price as the most important factor. However, the results of the questionnaire were different from their expectation, as quality of service provided to clients was the most important factor. Management studied the reasons for and developed solutions to counter the poor service. It found that there were several problems related to the mechanism of selecting workers in the customer service sector and that they were incompatible with the company's values and culture; moreover, there was a lack of training and development and extension programs for the workers. Therefore, the company decided to improve the selection process, boost its competencies, and increase the budget and training shares for customer service programs. With this intervention, the company's market share increased within two years.

Reference [8] shows that the success of a HR strategy depends on four primary areas. First is the implementation of an efficient recruitment process, which ensures quick access to the available labor pool. Second, the HR department should ensure that all staff members are intrinsically motivated. Third, 
the HR strategy should aim at developing skills, providing motivation, and building commitment in employees, and should design tasks so that agents have minimal organizational skill requirements. Finally, the HR department should be proficient in assessing employees' performance through monitoring calls and evaluating clients' satisfaction, since staff develops and becomes more motivated through constant appraisals.

In another case, after the development of the strategy, HR works to match the philosophy, policies, and programs of the strategy to help achieve goals at higher levels. The food products company $\mathrm{ABC}$ Distribution presents the most prominent example of the proactive role of HR in developing an organizational strategy. The company aims to make profits in sales and enhance growth and business development steadily through existing as well as new customers. Therefore, the HR department has developed its strategy considering the needs and objectives of the company. The HR team began to develop an action plan with an assessment of the skills of its human cadres. They predicted the number of managers required and the type of competencies needed. The team then laid down the foundations for modern HR systems to develop programs in training, skills development, leadership training, selection, polarization, and retention processes [4].

\section{Conclusion}

The HRM strategy is essential to enhancing the effectiveness of organizational operations. The HRM strategy is linked with the business strategy to ensure that it leads to the accomplishment of organizational goals and objectives. The HR department is crucial to ensuring the smooth running of corporate operations, by ensuring adequate access to human capital. The HRM strategy also explains the process to be followed while recruiting and selecting new employees. A good HRM strategy ensures that all employees are intrinsically motivated. This plays a key role in enhancing the activities of the organization. Furthermore, the HR department also maintains the organization's knowledge pool.

The paper also describes the importance of retaining employees. Employee retention can be achieved through motivating them in their work so that they provide the best quality of services. One way of motivating them is by implementing a reward scheme for those who perform well in their areas of assignment. The HR strategy should also promote a good relationship between employees and the HR department. This enhances the organization's success, mainly because it ensures good communications throughout the company.

\section{References}

[1] A. Al-Awlaki, "The impact of human resource management strategies on developing organizational creativity (field study)," University of Gezira Magazine, vol. 1 (1), p. 521, January 2018,8102 .
[2] Al Adresi and Darun, "Determining relationship between strategic human resource management practices and organizational commitment," International Journal of Engineering Business Management, vol. 9, pp. 1-9, 2017. DOI: 10.1177/1847979017731669 journals.sagepub.com/home/enb.

[3] Anon (2006) Strategic human resource management and its significance to service organisations [online]. Available from http://www.packet-one.com/docsp1/Thesis\%201.pdf.

[4] A. Armstrong, Strategic Human Resource Management: A Guide, $2^{\text {nd }}$ ed. Kogan Page Publishers, 2000. Available from http://books.google.co.uk/books?id=qMmc_89e-

14C\&pg=PA54\&dq=does + strategic + hr + work\&hl=en\&ei $=\mathrm{Uyb}$ kS8-

qEpPesAap_dUu\&sa $=X \&$ oi $=$ book_result\&ct=result\&resnum $=4 \& v e d=0$ CE0Q6AEwAw\#v $=$ onepage $\& \mathrm{q}=$ does $\% 20$ strategic $\% 20 \mathrm{hr} \% 20$ work $\& \mathrm{f}=$ false.

[5] B. Becker and Huselid, "Strategic human resources management: Where do we go from here?" Journal of Management [online], vol. 32, pp. 898-925, 2006.

[6] Bratton (2005) Strategic human resource management [online] Available

from http://www.palgrave.com/business/brattonandgold/docs/bgcha 02.pdf.

[7] W. Chang and Huang, "Relationship between strategic human resource management and firm performance: A contingency perspective," International Journal of Manpower [online], vol. 26 (5), pp. 434-439, 2005. Available from http://www.emeraldinsight.com/Insight/viewPDF.jsp?content Type $=$ Article $\&$ Filename $=$ html/Output/Published/EmeraldFull TextArticle/Pdf/0160260503.pdf.

[8] M. Catriona, Eagleson and Waldersee, "The sacrificial HR strategy in call centers," International Journal of Service Industry Management, Vol. 11 (2), pp. 174-185, 2000.

[9] OC and Johnson, "Strategic human resource management effectiveness and firm performance," The International Journal of Human Resource Management [online], vol. 12 (2), pp. 299 310, 2001. Available from http://www.emeraldinsight.com/Insight/viewContentItem.do?co ntentType $=$ Review\&contentId=1302236\&StyleSheetView=all.

[10] H. Saunders, "Gratterpalm uses HR as a strategic tool for growth," Strategic HR Review [online], vol. 8 (1), pp. 22-27, 2009. Available from http://www.emeraldinsight.com/Insight/viewContentItem.do?c ontent $T y p e=$ Article $\&$ contentId $=1756338$.

[11] F. Afzal, K. Mahmood, S. R. Sherazi, M. Sajid, and M. Hassan, "Effect of human resource planning on organizational performance of telecom sector," Information and Knowledge Management, vol. 3 (2), 2013. Available from http://www.iiste.org/.

[12] A.M. Alwehabie, "Criteria for measuring the efficiency and effectiveness of human resources management strategy and its relation to institutional performance at al Rajhi bank at al Qassim in Saudi Arabia from the employees' point of view," International Journal of Business and Management, vol. 12 (10), p. 111, 2017. doi: 10.5539/ijbm.v12n10p111.

[13] Deloitt, Enabling Business Results with HR "Measures that Matter," 2016. Available from https://www2.deloitte.com/content/dam/Deloitte/us/Document s/human-capital/us-hc-enabling-business-results-with-hrmeasures-that-matter.pdf. 
[14] B. Jovanovic, "Selection and the evolution of industry," Econometrica, vol. 50 (3), p. 649, 1982. doi: 10.2307/1912606.

[15] Y. Opoku-Mensah, "An analysis of human resource planning and its effect on organizational effectiveness: A case study of Information Services Department, Accra Office," 2012. (Master's thesis, Kwame Nkrumah University of Science and Technology, Accra, Ghana). Available from http://ir.knust.edu.gh/bitstream/123456789/4935/1/YAW\%20 OPOKU-MENSAH.pdf.

[16] M. R. Salah, "The Impact of Training and Development on Employees Performance and Productivity 'A case Study of Jordanian Private Sector transportation companies located in the Southern region of Jordan. A particular reference is made to the Govern ate of Maan'," International Journal of Management Sciences and Business Research, vol. 5 (7), 2016.

[17] J. O. Samwel, "An assessment of the impact of performance management on employee and organization performance: Evidence from selected private organizations in Tanzania," International Journal of Human Resource Studies, vol. 8 (3), p. 199, 2018. doi: 10.5296/ijhrs.v8i3.13415.

[18] J. W. Wachiuri, "Effect of performance appraisal on organizational performance: A case study of KPMG Kenya," 2017. (Master's thesis, United States International University, Nairobi, Kenya). Available from http://erepo.usiu.ac.ke/bitstream/handle/11732/3881/JULIET \%20W.\%20WACHIURI\%20MBA\%202018.pdf?isAllowed=y \&sequence $=1$.

[19] C. Zehir, Y. Gurol, T. Karaboga, and M. Kole, "Strategic human resource management and firm performance: The mediating role of entrepreneurial orientation," Procedia Social and Behavioral Sciences, vol. 235, pp. 372-381, 2016. doi: 10.1016/j.sbspro.2016.11.045.

[20] M. Armstrong, Armstrong's Handbook of Strategic Human Resource Management, Kogan Page Publishers, 2016.

[21] N. Batarlienė, K. Čižiūnienè, K. Vaičiūtè, I. Šapalaitè, and A. Jarašūnienè, "The impact of human resource management on the competitiveness of transport companies," Procedia Engineering, vol. 187, pp. 110-116, 2017.

[22] C. Brewster and A. Hegewisch, Policy and Practice in European Human Resource Management: The Price Waterhouse Cranfield Survey, Eds. Taylor \& Francis, 2017.

[23] E. A. Kasasbeh, Y. Harada, and I. M. Noor, "Developing a conceptual model for the relationship between human resource management, e-business strategies, and competitive advantage," The Journal of Internet Banking and Commerce, vol. 22 (1), 2017.

[24] A. Nankervis, M. Baird, J. Coffey, and J. Shields, Human Resource Management, Cengage AU, 2019.

[25] G. L. Stewart and K G. Brown, Human Resource Management, John Wiley \& Sons, 2019.

[26] S. Hassan, "Impact of HRM practices on employee's performance," International Journal of Academic Research in Accounting, Finance and Management Sciences, vol. 6 (1), pp. 15-22, 2016.

[27] A. Reddy, "A study on impact of HR strategies on employee performance in Abu Dhabi Distribution Company," International Journal of Social Science \& Interdisciplinary Research, vol. 2 (1), pp. 154-169, 2013.

[28] E. A. Sana, M. A. Atienza, and R. G. Nodora, "Developing human resources for health: The Philippines and Cambodian experience," New Zealand Journal of Asian Studies, vol. 18 (2), 2016.

[29] A. Sana A, N. Ali, and H. Misbah, "Critical assessment of the impact of HR strategies on employees' performance," Cogent Business \& Management, 2016, 3: 1245939 http://dx.doi.org/10.1080/23311975.2016.1245939.

[30] D. Tobeery, A. Almohtaseb, and M. Almahameed, "The role of human resources recruitment strategy in achieving organizational change at AL-Hussein Bin Talal UniversityJordan," Business and Economic Research, vol. 7 (2), p. 118, 2017. doi: 10.5296/ber.v7i2.11213. 